\title{
EFFECT OF KLEBSIELLA CAPSULAR ANTISERA ON LYMPHOCYTES FROM PATIENTS WITH ANKYLOSING SPONDYLITIS
}

\author{
Ruth Shinebaum, E. Mary CoOKe, \\ JILL SIEGERSTETTER* AND V. WRIGHT $\dagger$ \\ Departments of Microbiology and *Community Medicine and General Practice, \\ University of Leeds, Leeds LS2 $9 J T$ and $\dagger$ Rheumatism Research Unit, Department of \\ Medicine, The General Infirmary, Leeds LS1 3EX
}

\begin{abstract}
SUmmaRY. The cytotoxicity of klebsiella capsular antisera for lymphocytes from 10 HLA B27-positive patients with ankylosing spondylitis and eight B27-negative normal control subjects was examined. None of the antisera was cytotoxic for lymphocytes from nine patients but several antisera were cytotoxic for the lymphocytes from one patient. There were no differences between the results obtained with lymphocytes from the nine patients and those with lymphocytes from the normal controls. If klebsiella carriage is important in the pathogenesis of ankylosing spondylitis, the results of this investigation suggest that the capsular antigen is probably not involved.
\end{abstract}

\section{INTRODUCTION}

Seronegative arthritis may develop after infection by intestinal bacteria particularly, though not exclusively, in individuals who have the HLA B27 tissue antigen. Reiter's syndrome has followed infections with Shigella, where four out of five patients examined in one series were B27-positive (Calin and Fries, 1975), Salmonella (Vartiainen and Hurri, 1964) and Yersinia (Ahvonen, Sievers and Aho, 1969), but there are no reports of such infections giving rise to ankylosing spondylitis (AS), the disease most closely linked to the possession of the HLA B27 antigen.

Ebringer et al. (1976) demonstrated cross reactivity between B27-positive lymphocytes and Klebsiella aerogenes, Enterobacter aerogenes and Yersinia enterocolitica and Ebringer (1978) suggested that molecular mimicry may be the pathogenic mechanism. Ebringer et al. (1977) found that faecal carriage of klebsiellas in patients with AS was associated with active disease, but other workers could not confirm this observation (Eastmond, Cooke and Wright, 1978; Warren and Brewerton, 1979a). However, Ebringer, Cawdell and Ebringer (1979) and Eastmond et al. (1980) showed an association between klebsiella carriage and anterio uveitis but this was not supported by the findings of Warren and Brewerton (1979b), and sequential studies of klebsiella 
carriage have also produced conflicting results (Ebringer et al., 1978; Warren and Brewerton, 1980; Eastmond et al., 1981).

Geczy and co-workers (Geczy and Yap, 1979; Geczy et al., 1980a and b); showed that the lymphocytes from patients with AS who were B27 positive reacted with antisera prepared against klebsiellas of capsular types 21 and 43 but lymphocytes from B27-positive or B27-negative control subjects without AS did not. They concluded that there is cross reactivity between some klebsiella antigen(s) and either a cell-membrane structure closely associated with the B27 antigen or a genetically modified B27 antigen itself.

In an attempt to identify the cross-reacting antigens, we have investigated the lymphocytotoxicity of antisera prepared against 52 of the standard klebsiella capsular serotypes.

\section{MATERIALS AND METHODS}

The methods used to determine lymphocytotoxicity were based on those of Seager et al. (1979).

Sources of lymphocytes and antisera. Lymphocytes were obtained from 10 patients with AS and eight normal subjects. All the patients were B27 positive, two were female and all were outpatients. Two had acute anterior uveitis at the time of sampling and two had a previous history of this condition. All the controls were B27 negative, one was female and none had any history or familial association with AS or acute anterior uveitis.

Antisera against the standard klebsiella capsular serotypes were available in the laboratory. They had been prepared as described by Edmondson and Cooke (1979) for capsular typing of klebsiella by the quellung method. Antisera against 52 capsular types (K1-49, 52, 53 and 62) were used; antisera against the serotypes that we have found to be most common were used first and then the others in numerical order. The antisera had titres in the range 2-64, but neat antisera were used in all cases. Lymphocytes from patients from whom we had isolated klebsiellas in previous studies were always tested against antisera to the serotypes isolated. Human anti-B27 serum was tested against all the lymphocyte preparations.

Lymphocyte separation and labelling. Up to $60 \mathrm{ml}$ of blood was collected by venepuncture, preservative-free heparin 10 units $/ \mathrm{ml}$ were added and the mixture was diluted with an equal volume of Hanks's bile salts solution (HBSS). This was layered on to a Ficoll-Triosil density gradient (sp. gr. 1.077) and centrifuged at $650 \mathrm{~g}$ for $20 \mathrm{~min}$. The lymphocyte layer was removed and washed three times in HBSS with heparin $1 \mathrm{unit} / \mathrm{ml}$ and resuspended at a final concentration of $10^{7}$ lymphocytes/ml in RPMI 1640 (Flow Laboratories, Irvine, Scotland) containing $10 \%$ human $\mathrm{AB}$ serum. ${ }^{51} \mathrm{Cr}$ (Radiochemical Centre, Amersham, Bucks) $100 \mu \mathrm{C} / \mathrm{ml}$ was added to the lymphocyte suspension and incubated at $37^{\circ} \mathrm{C}$ for $60 \mathrm{~min}$. The cells were then washed three times in RPMI and resuspended in RPMI with $10 \%$ human AB serum at a concentration of $3 \times 10^{6}$ cells $/ \mathrm{ml}$.

Lymphocytotoxicity test. Antiserum $(100 \mu \mathrm{l})$ was added to $10 \mu \mathrm{l}$ of labelled cells and incubated at $24^{\circ} \mathrm{C}$ for $30 \mathrm{~min} ; 100 \mu \mathrm{l}$ of rabbit complement were then added and incubation was continued for a further $60 \mathrm{~min}$. The tubes were centrifuged at $1500 \mathrm{~g}$ for $15 \mathrm{~min}$ and $100 \mu \mathrm{l}$ of the supernate were removed for counting in a Packard Auto-gamma Spectrometer (model no. 3320, Packard Instruments, Caversham, Berks).

Minimal release was determined from a control preparation with cells, RPMI and complement. Maximal release was measured by adding $200 \mu \mathrm{l}$ of $2 \%$ Tween 80 to $100 \mu \mathrm{l}$ of cell suspension.

The results were expressed as a percentage of maximal ${ }^{51} \mathrm{Cr}$ release, calculated by the formula:

$$
{ }^{51} \mathrm{Cr} \text { release }(\%)=100 \times \frac{\mathrm{R}_{1}-\mathrm{R}_{2}}{\mathrm{R}_{3}-\mathrm{R}_{2}}
$$


where $R_{1}=$ radioactivity released by antiserum, $R_{2}=$ radioactivity released in absence of antiserum and $R_{3}=$ radioactivity released by cells disrupted by Tween 80 .

Each subject's lymphocytes were tested against anti-B27 serum and as many anti-klebsiella sera as the number of cells would allow. All tests were done in duplicate. In no case were there enough lymphocytes to test against all 78 klebsiella capsular antisera.

Statistical analysis. The results were analysed in two ways. Initially $50 \%{ }^{51} \mathrm{Cr}$ release was selected arbitrarily as the dividing line between a positive and negative result for cytotoxicity. The proportion of patients giving a positive or equivocal result with any of the antisera was compared with the proportion of controls giving a positive or equivocal result, by Fisher's exact test (Armitage, 1971). In the second analysis, the distribution of percentage ${ }^{51} \mathrm{Cr}$ release in the patients and controls was compared for each antiserum in turn, by the Mann-Whitney U test (Armitage, 1971). This test is equivalent to the Wilcoxon two-sample test. It avoids the assumptions of the $t$ test.

\section{RESULTS}

Two hundred and eighty-five tests with lymphocytes from patients and 117 tests with lymphocytes from controls were performed with klebsiella capsular antisera, and each lymphocyte suspension was also tested against anti-B27 serum. The results are shown in the table.

With $50 \%{ }^{51} \mathrm{Cr}$ release taken as a positive result, tests with anti-B27 serum gave one false negative $(34 \%$ and $41 \%$ release) and one equivocal result $(84 \%$ and $49 \%$ ). Most of the negative results obtained with klebsiella antisera were

\section{TABLE}

Cytotoxicity of anti-B27 and anti-klebsiella sera for lymphocytes from patients with AS and controls

\begin{tabular}{|c|c|c|c|c|c|}
\hline \multirow{2}{*}{$\begin{array}{l}\text { Subject no. } \\
\text { and status }\end{array}$} & \multirow{2}{*}{$\begin{array}{l}\text { Result with } \\
\text { anti-B27 } \\
\text { serum }\end{array}$} & \multirow{2}{*}{$\begin{array}{l}\text { Number of } \\
\text { klebsiella } \\
\text { antisera } \\
\text { tested }\end{array}$} & \multicolumn{3}{|c|}{ Number of results in category* } \\
\hline & & & negative & positive & equivocal \\
\hline 1. AS & - & 20 & 19 & 0 & 1 \\
\hline 2. AS & + & 15 & 15 & 0 & 0 \\
\hline 3. AS & + & 22 & 19 & 0 & 3 \\
\hline 4. AS & + & 13 & 13 & 0 & 0 \\
\hline 5. AS & + & 43 & 42 & 1 & 0 \\
\hline 6. AS & + & 49 & 31 & 11 & 7 \\
\hline 7. U(NA) & + & 51 & 48 & 0 & 3 \\
\hline 8. U(NA) & + & 25 & 25 & 0 & 0 \\
\hline 9. U(A) & $+1-$ & 26 & 18 & 0 & 8 \\
\hline 10. U(A) & + & 21 & 21 & 0 & 0 \\
\hline 11. Control & - & 33 & 32 & 0 & 1 \\
\hline 12. Control & - & 27 & 27 & 0 & 0 \\
\hline 13. Control & - & 14 & 13 & 0 & 1 \\
\hline 14. Control & - & 3 & 3 & 0 & 0 \\
\hline 15. Control & - & 6 & 6 & 0 & 0 \\
\hline 16. Control & - & 7 & 7 & 0 & 0 \\
\hline 17. Control & - & 8 & 7 & 1 & 0 \\
\hline 18. Control & - & 19 & 18 & 0 & 1 \\
\hline
\end{tabular}

$\mathrm{AS}=$ patient with ankylosing spondylitis but without history of uveitis; $\mathrm{U}(\mathrm{NA})=$ patient with ankylosing spondylitis and with a history of uveitis; $U(A)=$ patient with ankylosing spondylitis and active acute anterior uveitis. $+=$ Positive; $-=$ negative $+1-=$ equivocal.

${ }^{*}$ A positive result $={ }^{51} \mathrm{Cr}$ release $>50 \%$. 
in the range $0-25 \%$. Of the 402 tests done with klebsiella antisera, 25 gave equivocal results and 15 of these were with lymphocytes from two patients. Fisher's exact test showed no significant difference between the proportions of patients and controls that gave a positive result.

The results obtained with lymphocytes from patient no. 6 (see table) differed from those with lymphocytes from other patients and from the controls. The lymphocytes from patient no. 6 were tested against 49 antisera (K1-44, 46, 47, 49, 52 and 62). Eleven were cytotoxic (K1, 29, 30, 31, 34, 36, $37,39,40,41$ and 42$)$ and seven gave equivocal results (K 5, 20, 22, 24, 25, 32 and 35); the negative results in five of these were in the range $40-45 \%$.

To assess the effects of the individual antisera, the Mann-Whitney test was applied to the results obtained with the 13 antisera for which there were sufficient data (K1, 2, 3, 6, 7, 9, 10,12, 13, 16, 21, 27 and 35). A statistically significant difference between patients and controls was found for one capsular antiserum (K13) at the $5 \%$ level $(0.05>\mathrm{p}>0.01)$. Amongst 13 tests, one significant result at this level might easily occur when true differences are not present.

Lymphocytes from none of the four patients from whom klebsiellas had been isolated in previous surveys gave a positive or equivocal result with the antisera against the capsular types previously isolated.

\section{DisCUSSION}

In this study we have generally failed to demonstrate lymphocytotoxicity of klebsiella capsular antisera for lymphocytes from B27-positive patients with AS, although the lymphocytes of one patient were lysed by several antisera. Capsular antisera to types K21 and K43 were found to be cytotoxic for lymphocytes from patients with AS by Geczy et al. (1980a) but these antisera were not cytotoxic for lymphocytes from this patient. If there is any association between klebsiellas and AS, it is probably complex. Moreover, several mechanisms for the association of the HLA B27 antigen and AS have been proposed. These include the two-gene or linkage-disequilibrium theory which proposes that a disease-susceptibility gene is closely associated with the major histocompatibility complex (McDevitt and Bodmer, 1974). Other theories propose an interaction between the B27 antigen and an external agent. The cross-tolerance or molecular-mimicry theory is based on the possession by micro-organisms of antigens similar to human antigens (Jenkin, 1963). A more recent development has been the demonstration by Geczy et al. (1980b) that B27-positive lymphocytes from control subjects without AS can be modified by a filtrate of klebsiella serotype K43 so that they become as susceptible to lysis by klebsiella antisera as are B27-positive lymphocytes from patients with AS.

One difficulty in assessing this type of study is that the antigenic determinant that may be important has not been defined and may not have been exposed in the preparation of our klebsiella antisera. In the present study, as in that of Geczy and co-workers (Seager et al., 1979), formalinised 
cultures were used to raise antisera but the immunisation schedules were different and we did not use Freund's adjuvant, which may increase the immunological response and, possibly, lower its specificity.

Klebsiella antisera were cytotoxic for lymphocytes from only one patient in the present study and the lymphocytes of this patient reacted with antisera to many klebsiella capsular types. The antisera that were cytotoxic for this patient's lymphocytes did not show cross reactions in the quelling reaction and a common klebsiella antigen was probably involved.

With the exception of this evidence of toxicity of klebsiella antisera for lymphocytes of one patient, the results reported here suggest that the results obtained by other workers are probably not due to the klebsiella capsular antigen but may be caused by some other bacterial structure that was antigenic in their immunisation schedules but was not antigenic in our schedule for the production of capsular antisera.

We are indebted to Dr S. M. Rajah, of the Blood Transfusion Centre, Leeds, for providing the anti-B27 serum.

\section{REFERENCES}

Ahvonen, P., Sievers, K. AND Aho, K. 1969. Arthritis associated with Yersinia enterocolitica infection. Acta rheum. scand., 15, 232.

ARmitaGe, P. 1971. Statistical methods in medical research, Blackwell Scientific, Oxford, pp. $135-138$, and 397-403.

Calin, A. AND Fries, J. F. 1975. Epidemic Reiter's syndrome. Genetics and environment. Arthritis Rheum., 18, 390.

Eastmond, C. J., Calguneri, M., Shinebaum, R., Cooke, E. M. and Wright, V. 1981. A sequential study of the relationship between faecal Klebsiella aerogenes and the common clinical manifestations of ankylosing spondylitis. Ann. rheum. Dis., (in the press).

Eastmond, C. J., CoOKe, E. M. AND Wright, V. 1978. Klebsiella pneumoniae. Ann. rheum. Dis., 37, 298.

Eastmond, C. J., Willshaw, H. E., Burgess, S. E. P., Shinebaum, R., Cooke, E. M. and WRIGHT, V. 1980. Frequency of faecal Klebsiella aerogenes in patients with ankylosing spondylitis and controls with respect to individual features of the disease. Ann. rheum. Dis., 39, 118.

Ebringer, A. 1978. The link between genes and disease. New Scient., 79, 865.

Ebringer, R. W., CaWdell, D. R., Cowling, P. AND Ebringer, A. 1978. Sequential studies in ankylosing spondylitis. Association of Klebsiella pneumoniae with active disease. Ann. rheum. Dis., 37, 146.

EBRINGER, R., CAWDELl, D. AND EBRINGER, A. 1979. Klebsiella pneumoniae and acute anterior uveitis in ankylosing spondylitis. Br. med. J., $1,383$.

Ebringer, R., CoOKe, D., CAWDell, D. R., Cowling, P. ANd Ebringer, A. 1977. Ankylosing spondylitis: klebsiella and HL-A B27. Rheum. Rehab., 16, 190.

Ebringer, A., Cowling, P., Ngwa SuH, N., JAmes, D. C. O. AND Ebringer, R. W. 1976. Cross reactivity between Klebsiella aerogenes species and B27 lymphocyte antigens as an aetiological factor in ankylosing spondylitis. In HLA and disease, edited by J. Dausset and A. Svejgaard, collague no. 58, I.N.S.E.R.M., Paris, p. 27.

Edmondson, A. S. AND COOKE, E. M. 1979. The production of antisera to the klebsiella capsular antigens. J. appl. Bact., 46, 579.

GeCZY, A. F., AleXander, K., BASHIR, H. V. AND EDMONDS, J. 1980b. A factor(s) in klebsiella culture filtrates specifically modifies an HLA-B27-associated cell-surface component. Nature, Lond., 283, 782. 
Geczy, A. F., Bashir, H. V., Alexander, K. And Edmonds, J. P. 1980a. Cross-reactivity between environmental agents and HLA-B27. Lancet, 1, 50.

GECZY, A. F. AND YAP, J. 1979. HLA-B27, Klebsiella and ankylosing spondylitis. Lancet, 1, 719.

Jenkin, C. R. 1963. Heterophile antigens and their significance in the host-parasite relationship. Adv. Immunol., 3, 351 .

MCDEvitT, H. O. AND BoDMER, W. F. 1974. HLA immune response genes and disease. Lancet, 1, 1269.

Seager, K., Bashir, H. V., Geczy, A. F., Edmonds, J. and De Vere-Tyndall, A. 1979. Evidence for a specific B27-associated cell surface marker on lymphocytes of patients with ankylosing spondylitis. Nature, Lond., 277, 68.

VARTIAINEN, J. AND HURRI, L. 1964. Arthritis due to Salmonella typhimurium. Report of 12 cases of migratory arthritis in association with Salmonella typhimurium infection. Acta med. scand., 175, 771.

WARREN, R. E. AND BREWERTON, D. A. 1979a. Faecal carriage of klebsiella by patients with ankylosing spondylitis and rheumatoid arthritis. Ann. rheum. Dis., 38, 186.

WARREN, R. E. AND BREWERTON, D. A. 1979b. Klebsiella, spondylitis and uveitis. Br.med. J., $1,889$.

WARREN, R. E. AND BREWERTON, D. A. 1980. Faecal carriage of klebsiella by patients with ankylosing spondylitis and rheumatoid arthritis. Ann. rheum. Dis., 39, 37. 